\title{
Tissue concentration, mRNA expression and stimulation of IGF-I in luteal tissue during the oestrous cycle and pregnancy of cows*
}

\author{
R. Einspanier, A. Miyamoto, D. Schams, M. Müller† and G. Brem† \\ Institut für Physiologie, TU München, 8050 Freising-Weihenstephan, FRG; and \\ $\dagger$ Lehrstuhl für Molekulare Tierzucht, LMU München, FRG
}

\begin{abstract}
Summary. The expression of IGF-I in bovine luteal tissue was demonstrated by parallel measurement of IGF-I tissue concentration and its mRNA; highest synthesis was observed during Days 12-17 of the cycle and the first months of pregnancy. Tissue levels of IGF-I increased from Days 1-5 to Days 12-17 of the cycle followed by a rapid decrease at luteolysis; there was a continuous decline from early pregnancy until Months 6-9. Microdialysis perfusion experiments with corpora lutea in vitro at Days 8-11 of the cycle revealed a major effect: release of progesterone and oxytocin were highly stimulated in a dose-dependent manner. We suggest that IGF-I could be important in regulating the function of the bovine corpus luteum and may act in an autocrine/paracrine way.
\end{abstract}

Keywords: corpus luteum; IGF-I; expression; cattle

\section{Introduction}

The list of hormones and growth factors which have effects on the development and proliferation of ovarian tissue has grown considerably. The classical concept of endocrine control of ovarian function has been extended to paracrine and autocrine mechanisms and the local synthesis of growth factors in ovarian cells (IGF-I, TGF) has been reported (Skinner \& Coffey, 1988; Oliver et al., 1989). IGF-I especially appears to have important stimulatory effects on ovarian regulation: e.g. steroidogenesis in follicles (Spicer et al., 1988), DNA synthesis and cell proliferation (May et al., 1988) and stimulation of progesterone and oxytocin in bovine granulosa cells (Schams et al., 1988), stimulation of aromatase activity (Adashi et al., 1985) and amplification of FSH action (Davoren $e t$ al., 1985; Adashi et al., 1988) in human and rat granulosa cells. Recent data have been published about the stimulation and secretion of IGF-I in granulosa cells in vitro to examine differences during folliculogenesis (Hernandez et al., 1989; Mondschein et al., 1989). The aim of this study was to measure tissue concentrations of IGF-I and its mRNA in bovine corpus luteum during the oestrous cycle. A special perfusion technique in vitro was applied to demonstrate local effects.

\section{Materials and Methods}

The corpora lutea (CL) from mainly German Fleckvieh heifers were collected from a local slaughterhouse within 10-20 min of slaughter. The stage of the cycle was defined by macroscopic observation of the ovaries (follicles and corpus luteum) and the uterus (size, colour, consistency, connective tissue and mucus). The corpora lutea were divided into four groups during the oestrous cycle (Days $1-5,6-11,12-17,18-21$ after ovulation) and three groups during pregnancy (Months 1-2, 3-5, 6-9). IGF-I was extracted from 5 CL per group and the same tissue (i.e. $5 \mathrm{CL}$ ) was analysed for IGF-I mRNA by two independent experiments. If the cow was pregnant, the crown-rump length of the

*Reprint requests to D. Schams. 
fetus was measured to evaluate the stage of pregnancy. Corpora lutea were separated immediately and stored in liquid nitrogen until extraction for RNA and IGF. For the incubation experiment, CL were washed with saline $(0 \cdot 154 \mathrm{M})$ at $38^{\circ} \mathrm{C}$ several times, then kept in Medium 199 (Sigma, Munich, FRG) at pH 7.2, $38^{\circ} \mathrm{C}$ containing $10 \mathrm{mmol}$ $\mathrm{NaHCO}_{3} / 1$, Earle's salts, L-glutamine, $25 \mathrm{mmol}$ Hepes $/ 1,0.5 \%$ (w/v) bovine serum albumin, $60 \mathrm{mg}$ penicillin $/ 1,100 \mathrm{mg}$ streptomycin/l, $2 \mathrm{mg}$ amphotericin/l and $65 \mathrm{mg}$ ascorbic acid/1 (M199).

Hormone measurement. IGF-I in luteal tissue was measured by RIA after acid-ethanol extraction of the tissue. Tissue $(0.2 \mathrm{~g}$ wet weight) was homogenized in a dismembranator (Braun, Melsungen, FRG) for $30 \mathrm{sec}$, cooled with liquid nitrogen and suspended in 3 volumes of $2 \mathrm{M}$-acetic acid/75 mM- $\mathrm{NaCl}$. Extraction was done for $30 \mathrm{~min}$ at room temperature to separate IGF from its binding proteins (Daughaday et al., 1980). After a brief centrifugation (10 min at $10000 \mathrm{~g}$ ) $50 \mu \mathrm{l}$ of supernatant were extracted again and assayed by an IGF-I RIA. Validation of IGF-I tissue extraction was done by neutral gel filtration $(40 \times 1.6 \mathrm{~cm}$ column of Sephacryl 200: Pharmacia, Freiburg, FRG). Tissue extracts were neutralized, incubated for $1 \mathrm{~h}$ with labelled IGF-I and separated by gel chromatography. Fractions were measured for radioactivity in a gamma counter (LKB-Pharmacia, Freiburg, FRG). Distribution of endogenous IGF-I in the extracts was analysed by neutral gel filtration followed by determination of IGF-I in each fraction by RIA.

Recombinant human IGF-I (Amersham, Bucks, UK) was iodinated according to the lactoperoxidase method (Marchalonis, 1969). Synthetic IGF-I (kindly provided by the late C. H. Li, San Francisco, CA, USA) was used as a reference preparation. The antiserum from a rabbit was kindly supplied by $P$. Gluckman (Auckland, New Zealand) and showed no cross-reaction with related peptides such as insulin, proinsulin or IGF-II. Validation for tissue extraction was done by means of dilution curves and recovery experiments ( $92 \%$ recovery of labelled IGF-I). Separation of bound and free hormone was performed by a second antibody and polyethylene glycol (I $2 \%$ ). Samples have been measured in duplicate. The intra-assay and inter-assay variations were $<9 \%$ and $<14 \%$ respectively.

Progesterone and oxytocin concentrations in the perfusate fractions were determined directly by enzymeimmunoassay (Prakash et al., 1987) and radioimmunoassay (Schams, 1983), respectively.

$\boldsymbol{R N A}$ detection. Total RNA was isolated from luteal tissue by the guanidinium isothiocyanate method according to Maniatis et al. (1982). RNA northern blots were carried out on Hybond-ECl membrane (Amersham) after fractionation of total RNA in a $0.8 \%$ formaldehyde-agarose gel following the instructions of the manufacturer. The 542 bp cDNA coding for pig IGF-I (pIGF-I) has been published (Müller \& Brem, 1990). Hybridization and detection of mRNA blots were done under stringent conditions according to the non-radioactive ECl gene detection system (Amersham).

Microdialysis perfusion system in vitro. Basically, the microdialysis method by Jarry et al. (1987) was used with modification for the in-vitro organ culture. In brief, the corpus luteum (Days 8-12 of the oestrous cycle) was cut with a scalpel to a 10-12 $\mathrm{mm}$ cube, and bisected. These two identical pieces were distributed to different IGF-I dose groups. Each luteal piece was penetrated by a $8-10 \mathrm{~mm}$ long dialysis capillary (Amicon Vitafiber $3 \mathrm{~S} 100$; cut off $M_{\mathrm{r}} 100000$ ), with each end attached to Silastic tubings (i.d. $0.3 \mathrm{~mm}$ ) by glue. The Silastic tubings were fixed on the face of the luteal piece by Histoacryl blau (B. Braun-Dexon GmbH, Spangenberg, FRG), so that the portion of dialysis capillary was held in the luteal piece. For the perfusion, one of the tubes was connected to a peristaltic pump, and the other was joined to the fraction collector. After connection to these systems, the luteal pieces penetrated by dialysis capillary were maintained in organ culture chambers (2070 Tube, Falcon, USA) filled with $50 \mathrm{ml}$ M 199 , that were kept in a water bath at $38^{\circ} \mathrm{C}$. Fresh M 199 was dropped into the chamber at the rate of $15 \mathrm{ml} / \mathrm{h}$ from the top, and the medium flowed out at the same rate from the bottom driven by a peristaltic pump. During setting up the system, luteal pieces were always maintained in $\mathrm{M} 199$ at $38^{\circ} \mathrm{C}$. Just after the start of the incubation, luteal pieces were perfused by Ringer's solution at a rate of $1 \mathrm{ml} / 10 \mathrm{~min}$ for $8 \mathrm{~h}$. After $3 \mathrm{~h}$ preincubation, every 10 -min perfusate fraction was collected for $5 \mathrm{~h}$. Because of the great individual variations of hormone concentrations between luteal pieces, the mean progesterone or oxytocin concentrations of the first 6 fractions ( $1-\mathrm{h}$ perfusion) were used for calculation of an individual baseline $(100 \%)$. All hormone concentrations in fractions from each piece were then expressed as a percentage of individual baseline. This step allows comparison of the effect of IGF-I on secretion of hormone between different dose groups. Additionally the absolute concentrations (mean, range) are given. IGF-I $(750 \mu \mathrm{g})$ was dissolved in $50 \mu 1 \mathrm{mM}-\mathrm{HCl}$ and diluted with Ringer's solution to a concentration of $100 \mu \mathrm{g} / \mathrm{ml}(6.7 \mu \mathrm{M}-\mathrm{HCl})$, and stored at $-20^{\circ} \mathrm{C}$ as a stock solution. IGF was further diluted with Ringer's solution just before the start of the experiment to a final concentration (range of $0 \cdot 2-10 \mu \mathrm{g} / \mathrm{ml}$ for $30 \mathrm{~min}$ ). Fractions were stored at $-20^{\circ} \mathrm{C}$ until determination of progesterone and oxytocin. The diffusion capacity of the membrane was about $1 \%(0 \cdot 5-2 \%)$ of infusate concentration as controlled by ${ }^{125}$ I-labelled IGF-I.

Statistical analysis. Concentrations of IGF-I in the corpus luteum at different stages of the oestrous cycle and pregnancy were analysed by split-plot analysis of variance and Duncan's new multiple range test.

\section{Results}

\section{IGF-I in cyclic corpus luteum}

Concentrations of IGF-I in tissue of bovine corpus luteum changed during the oestrous cycle (Fig. 1a). Low amounts of IGF-I could be detected on Days $1-5(227 \pm 31 \mathrm{ng} / \mathrm{g}$ wet weight $)$, higher 
concentrations on Days 6-11 (465 $\pm 50 \mathrm{ng} / \mathrm{g})$ and the maximum during the late luteal phase on Days $12-17(1057 \pm 269 \mathrm{ng} / \mathrm{g})$ followed by a rapid decrease after luteolysis on Days 18-21 $(172 \pm 51 \mathrm{ng} / \mathrm{g})$. Blood concentrations of IGF-I during the whole oestrous cycle showed a concentration of about $600 \pm 180 \mathrm{ng} / \mathrm{ml}$. Gel filtration experiments with tissue extracts demonstrated the presence of IGF-I binding proteins (large and small) in the luteal tissue. Striking differences of the binding capacity of mainly the small binding protein could not be detected during the cycle (data not shown). In the final extract for RIA most of the IGF-I was eluted in the fraction of $M_{\mathrm{r}} 7500$, indicating removal of binding proteins. Using this technique we were able to exclude interfering binding proteins during the IGF RIA.
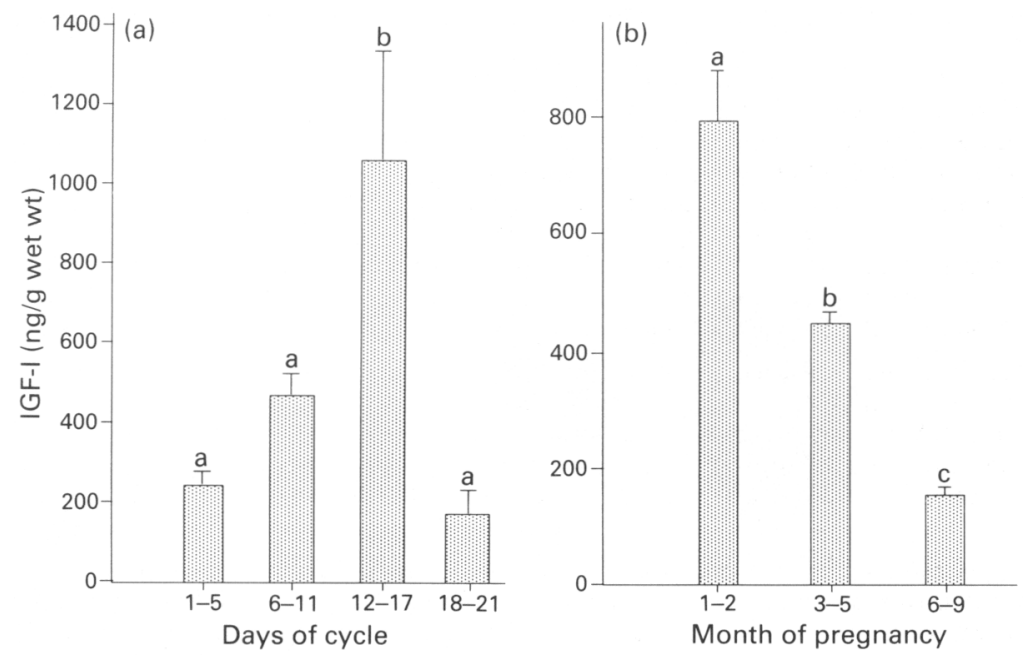

Fig. 1. Concentrations of IGF-I in bovine luteal tissue during (a) the oestrous cycle and (b) pregnancy. Values are mean \pm s.e.m. for (a) 5-9 and (b) 5-6 CL and cows per group. Values with different superscripts differ significantly $(P<0.01)$.

Hybridization experiments with an IGF-I-specific cDNA (pIGF-I) yielded a main mRNA species of about $4 \mathrm{~kb}$. Low IGF-I mRNA concentrations on Days 1-5 and 18-21 of the cycle were obvious (Fig. 2a), but higher values were present on Days 6-11 and were maximal on Days 12-17. The RNA hybridization experiments were done twice for each CL with various RNA preparations and showed similar results.

\section{IGF-I in the corpus luteum during pregnancy}

Values decreased significantly during pregnancy from the highest level of $812 \pm 86 \mathrm{ng} / \mathrm{g}$ at the first month to $450 \pm 14 \mathrm{ng} / \mathrm{g}$ during Months $3-5$ to $146 \pm 14 \mathrm{ng} / \mathrm{g}$ after 6 months of pregnancy (Fig. lb). The northern blot experiment done with total RNA from the same CL demonstrated high expression of IGF-I mRNA during the first months of pregnancy, very little during Months 3-5 and none during Months 6-9 (Fig. 2b).

\section{Effect of IGF-I on the secretion of luteal tissue}

The baseline of perfusate fractions from luteal pieces (Days 8-12) varied between 0.41 and $5.37 \mathrm{ng} / \mathrm{ml}$ (mean $2.16 \mathrm{ng} / \mathrm{ml}$ ) for progesterone and between 6.7 and $51.3 \mathrm{pg} / \mathrm{ml}(\mathrm{mean} 20.6 \mathrm{pg} / \mathrm{ml}$ ) for oxytocin. IGF-I stimulated the release of both progesterone and oxytocin (Fig. 3) in a dosedependent manner from microdialysed luteal pieces in vitro. For progesterone, a release pattern of 2 
(a)

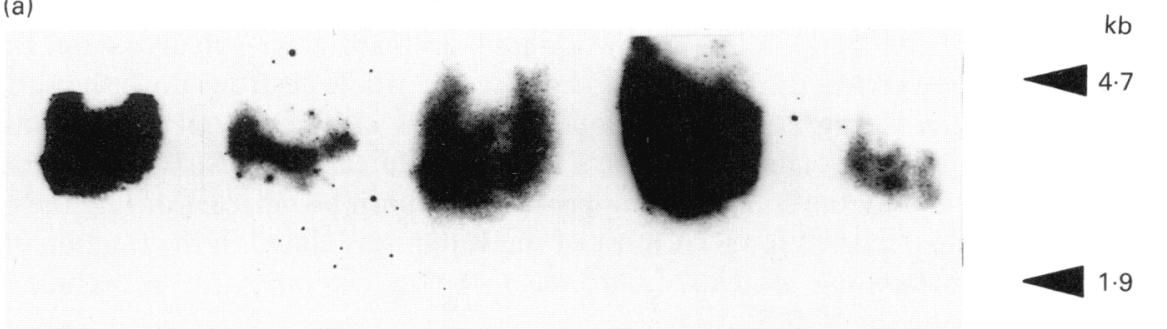

$\begin{array}{lll}\text { Liver } & 1-5 & 6-11 \quad 18-21 \\ \text { (b) } & \text { Days of cycle }\end{array}$

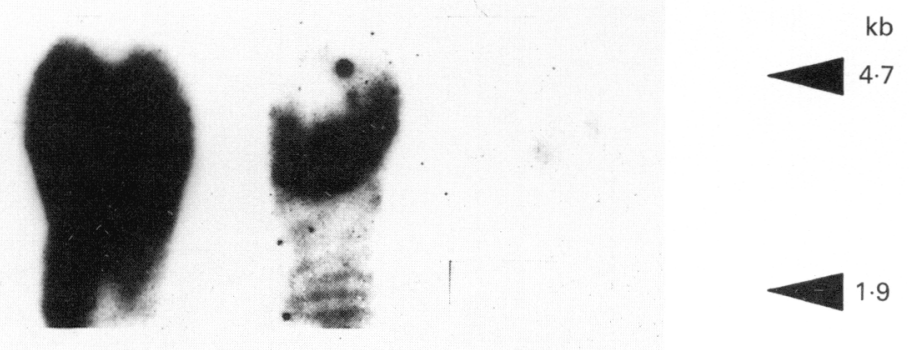

1-2 3-5 6-9

Months of pregnancy

Fig. 2. Concentrations of specific mRNA in bovine corpus luteum during (a) the oestrous cycle and (b) pregnancy. Northern hybridization with pIGF-I-cDNA was used and $30 \mu \mathrm{g}$ total RNA per lane were separated by electrophoresis on a $0.8 \%$ formaldehyde-containing agarose gel. Detection was by the non-radioactive $\mathrm{ECl}$ system (Amersham, Bucks, UK).

or 3 waves was apparent after the first peak directly related to infusion of IGF-I, but no such pattern was seen for the release of oxytocin.

\section{Discussion}

We investigated in this study the distribution and function of the growth factor IGF-I in bovine luteal tissue. For the first time an expression of IGF-I in the bovine corpus luteum could be demonstrated by determining both IGF-I-specific mRNA and the peptide concentrations. Under our conditions, a main IGF-I RNA species, about $4 \mathrm{~kb}$ in length, could be detected and was comparable with liver RNA. Similar data have been reported for other species (van Neste et al., 1988; Freed \& Herington, 1989). Concentrations of IGF-I in this tissue correlated with the expression 

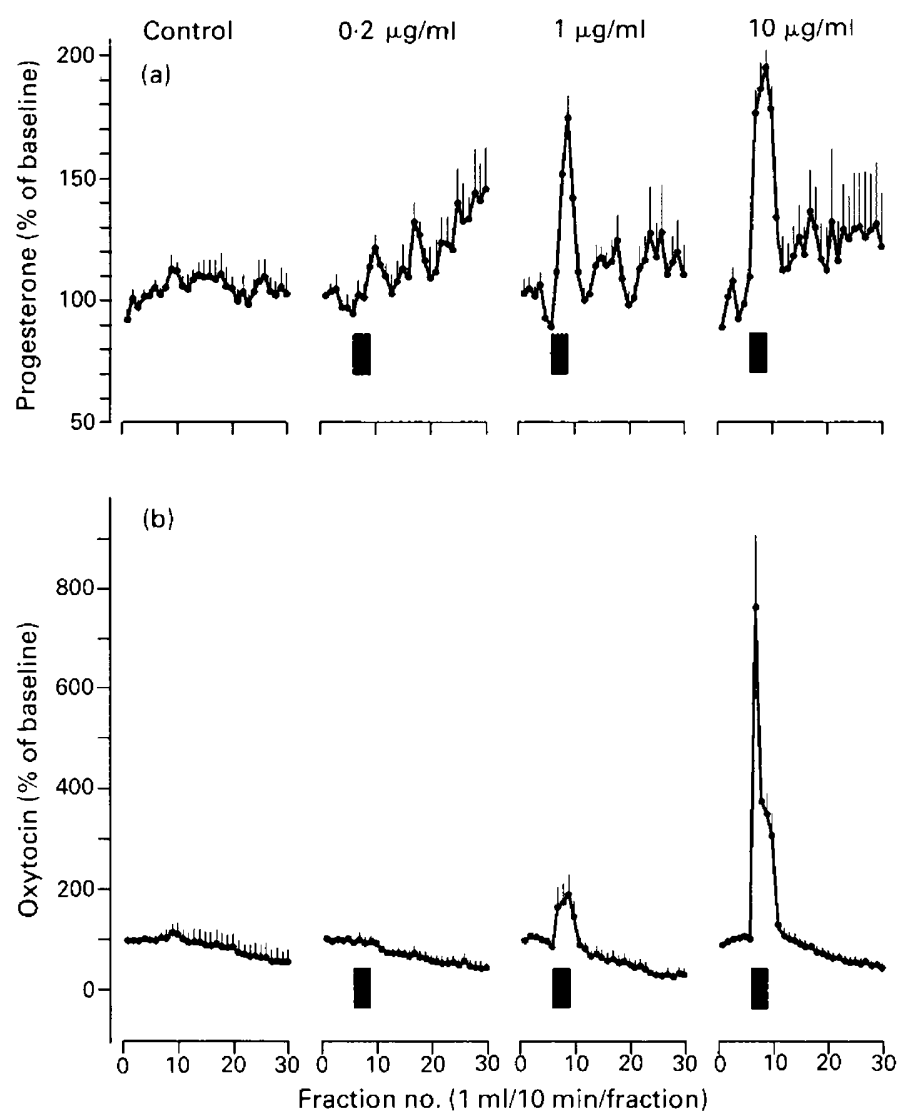

Fig. 3. Dose-dependent release of (a) progesterone and (b) oxytocin from microdialysed bovine luteal tissue (Days 8-12 of the oestrous cycle) in vitro after stimulation with IGF-I $(0 \cdot 2,1$ and $10 \mu \mathrm{g} / \mathrm{ml}$ ). The filled bars indicate IGF-I application. All values are shown as \% of baseline (mean \pm s.e.m.; $n=5 \mathrm{CL}$ and cows per group) calculated from the first 6 fractions. Absolute concentrations ranged from 0.41 to $5.37 \mathrm{ng}$ progesterone $/ \mathrm{ml}$ (mean $2.16 \mathrm{ng} / \mathrm{ml}$ ) and 6.7 to $51 \cdot 3 \mathrm{pg}$ oxytocin $/ \mathrm{ml}$ (mean $20 \cdot 6 \mathrm{pg} / \mathrm{ml})$.

of mRNA. An accumulation of liver-derived IGF-I in the corpus luteum therefore seems to be unlikely. We used a pig IGF-I clone for the RNA hybridization experiments because evolutionarily conserved protein and RNA sequences for IGF-I have been reported for human, pig, rat and sheep (Bell et al., 1986; Honegger \& Humbel 1986; Rotwein, 1986; Lund et al., 1986; Tavakkol et al., 1988; Francis et al., 1989). Moreover, a bovine IGF-I-cDNA has been isolated (Fotsis et al., 1990) and an homology of $92 \%$ to the pig sequence is present.

Several recent observations have suggested IGF-I as a potential factor in the ovary and that it could act as a regulator of granulosa cell differentiation (Schams et al., 1988; Holtorf et al., 1989). The expression of IGF-I in rat ovarian tissue, especially granulosa cells, has been demonstrated by RNA techniques to be dependent on the developmental status (Carlsson et al., 1989; Hernandez et al., 1989; Oliver et al., 1989). These reports suggest a major synthesis of IGF-I in granulosa cells of antral follicles and thereby a stimulation of proliferation and differentiation. Oliver et al. (1989) found that IGF-I expression could only be detected in granulosa cells but not in the corpus luteum of rats. In contrast to these observations, we were able to measure maximal expression of IGF-I in the bovine corpus luteum during the late luteal phase of the cycle and early pregnancy which is correlated with a high metabolic activity of this tissue. We have shown an immediate and dosedependent release of progesterone and oxytocin after IGF-I by microdialysed luteal tissue during 
that period. McArdle \& Holtorf (1989) measured a similar response after long-term incubation of dispersed luteal cells. The difference in the effective time for response of luteal tissue between the two systems may suggest an important role of cell contact. Saturable, specific and high-affinity IGF-I receptors have been demonstrated on the granulosa cells of ewes (Monget et al., 1989), women (Gates et al., 1987) and rats (Adashi et al., 1989). We assume that the similar presence of type I receptors on luteal cells and that the effect of IGF-I is mediated via membrane receptors. Perfusion with vehicle alone (Ringer and $\mathrm{HCl}$ ) was ineffective and a non-specific effect can therefore be excluded. Sensitivity of luteal tissue to IGF-I is high after the mid-luteal phase. This parallels a high expression in the same tissue and seems to be independent of concentrations of IGF-I in blood. We therefore suggest an autocrine/paracrine function of IGF-I in the corpus luteum, especially during the mid- and late luteal phase of the cycle and during early pregnancy. Similar effects are postulated for human, rat and pig granulosa cell differentiation and growth (Mondschein et al., 1989; Holly \& Wass, 1989). Further work has to be done to elucidate the role of IGF-I in the ovary, especially in the corpus luteum. Interest should be focussed on IGF-I receptors and the localization of IGF-I synthesis in different luteal cells.

\section{References}

Adashi, E.Y., Resnick, C.E., Brodie, A.M.H., Svoboda, M.E. \& Van Wyk, J.J. (1985) Somatomedin C mediated potentiation of follicle-stimulating hormone-induced aromatase activity of cultured rat granulosa cells. Endocrinology 117, 2369-2374.

Adashi, E.Y., Resnick, C.E., Hernandez, E.R., May, J.V., Knecht, M., Svoboda, M.E. \& Judson, J. (1988) IGF-I as an amplifier of follicle-stimulating hormone: studies on mechanism and sites of action in cultured rat granulosa cells. Endocrinology 122, 1583-1591.

Adashi, E.Y., Resnick, C.E. \& Rosenfeld, R.G. (1989) IGF-I and IGF-II hormonal action in cultured rat granulosa cells: mediation via type I but not type II IGF receptors. Endocrinology 126, 216-222.

Bell, G.l., Stempien, M.M., Fong, N.M. \& Rall, L.B. (1986) Sequences of liver cDNAs encoding two different insulin-like growth factor I precursors. Nucleic Acids Res. 14, 7873-7882.

Carlsson, B., Carlsson, L. \& Billig, H. (1989) Estrous cycle-dependent co-variation of IGF-I mRNA and protein in the rat ovary. Molec. cell. Endocr. 64, 271-275.

Daughaday, W.H., Mariz, I.K. \& Bleten, S.L. (1980) Inhibition of access of bound somatomedin to membrane receptor and immunobinding sites: a comparison of radioreceptor and radioimmunoassay of somatomedin in native and acid-ethanol-extracted serum. J. clin. Endocr. Metab. 51, 781-788.

Davoren, J.B., Hsueh, A.J.W. \& Li, C.H. (1985) Somatomedin $\mathrm{C}$ augments FSH-induced differentiation of cultured rat granulosa cells. Am. J. Physiol. 249, E26-E33.

Fotsis, T., Murphy, C. \& Gannon, F. (1990) Nucleotide sequence of the bovine insulin-like growth factor 1 (IGF1) and its IGF1A precursor. Nucleic Acids Res. 18, 676 .

Francis, G.L., McNeil, K.A., Wallace, J.C., Ballard, J.F. \& Owens, P.C. (1989) Sheep insulin-like growth factors I and II: sequences, activities and assays. Endocrinology 124, 1173-1183.

Freed, K.A. \& Herington, A.C. (1989) Insulin-like factor$\mathrm{I}$ and its autocrine role in growth of MCF-/human breast cancer cells in culture. J. molec. Endocr. 3, 183-190.

Gates, G.S., Bayer, S., Seibel, M., Poretsky, L., Flier, J.S. \& Moses, A.C. (1987) Characterization of IGF binding to human granulosa cells obtained during in vitro fertilization. J. Receptor Res. 7, 885-902.

Hernandez, E.R., Roberts, C.T., LeRoith, D. \& Adashi, E.Y. (1989) Rat ovarian IGF-I gene expression is granulosa-selective: $5^{\prime}$-untranslated mRNA variant representation and hormonal regulation. Endocrinology 125, 572-574.

Holly, J.M.P. \& Wass, J.A.H. (1989) Insulin-like growth factors; autocrine, paracrine or endocrine? New perspectives of the somatomedin hypothesis in the light of recent developments. J. Endocr. 122, 611-618.

Holtorf, A.-P., Furuya, K., Ivell, R. \& McArdle, C.A. (1989) Oxytocin production and oxytocin mRNA levels in bovine granulosa cells are regulated by IGFI: dependence on developmental status of the ovarian follicle. Endocrinology 125, 2612-2620.

Honegger, A. \& Humbel, R.E. (1986) Insulin-like growth factors I and II in fetal and adult bovine serum. $J$. biol. Chem. 261, 569-575.

Jarry, H., Dietrich, M., Düker, E. \& Wuttke, W. (1987) Effects of systemic and local administration of etomidate on adrenocortical steroidogenesis in male rats. Acta endocr., Copenh. 114, 402-409.

Lund, P.K., Moats-Staats, B.M., Hynes, M.A., Simmons, J.G., Jansen, M., D'Ercole, A.J. \& Van Wyk, J.J. (1986) Somatomedin-C/IGF-I and IGF-II mRNAs in rat fetal and adult tissues. J. biol. Chem. 26, 14539-14544.

Maniatis, T., Fritsch, E.F. \& Sambrook, J. (1982) Molecular Cloning: a Laboratory Manual. Cold Spring Harbor Lab.

Marchalonis, J.J. (1969) An enzymic method for the trace iodination of immunoglobulins and other proteins. Biochem. J. 113, 299-232.

May, J.V., Frost, J.P. \& Schomberg, D.W. (1988) Differential effects of epidermal growth factor, insulin-like factor I and transforming growth factor beta on 
porcine granulosa cell DNA synthesis and cell proliferatión. Endocrinology 123, 168-179.

McArdle, C.A. \& Holtorf, A.-P. (1989) Oxytocin and progesterone release from bovine corpus luteal cells in culture: effects of IGF-I, insulin and prostaglandins. Endocrinology 124, 1278-1286.

Mondschein, J.S., Canning, S.F., Miller, D.Q. \& Hammond, J.M. (1989) IGFs as autocrine/paracrine regulators of granulosa cell differentiation and growth: studies with a neutralizing monoclonal antibody to IGF-I. Biol. Reprod. 40, 79-85.

Monget, P., Monniaux, D. \& Durand, P. (1989) Localization, characterization and quantification of IGF-I binding sites in the ewe ovary. Endocrinology 125, 2486-2493.

Muiller, M. \& Brem, G. (1990) Nucleotide sequence of porcine insulin-like growth factor I: $5^{\prime}$ untrans!ated region, exons 1 and 2 and mRNA. Nucleic Acids Res. 18 (in press).

Oliver, J.E., Aitman, T.J., Povell, J.F., Wilson, C.A. \& Clayton, R.N. (1989) IGF-I gene expression in the rat ovary is confirmed to the granulosa cells of developing follicles. Endocrinology 124, 2671-2679.

Prakash, B.S., Meyer, H.H.D., Schallenberger, E. \& van de Wiel, D.F.M. (1987) Development of a sensitive enzymeimmunoassay (EIA) for progesterone determination in unextracted bovine plasma using the second antibody technique. J. Steroid Biochem. 28, $623-627$.
Rotwein, P. (1986) Two insulin-like growth factor-I mRNAs are expressed in human liver. Proc. natn. Acad. Sci. USA 83, 77-81.

Schams, D. (1983) Oxytocin determination by radioimmunoassay-improvement to subpicogram sensitivity and application to blood levels in cyclic cattle. Acta endocr., Copenh. 103, 180-183.

Schams, D., Koll, R. \& Li, C.H. (1988) Insulin-like growth factor I stimulates oxytocin and progesterone production by bovine granulosa cells in culture. $J$. Endocr. 116, 97-100.

Skinner, M.K. \& Coffey, R.J. (1988) Regulation of ovarian cell growth through the local production of TGF $\alpha$ by theca cells. Endocrinology 123, 2632-2638.

Spicer, L.J., Echternkamp, E., Canning, S.F.\& Hammond, J.M. (1988) Relationship between concentrations of immunoreactive IGF-I in follicular fluid and various biochemical markers of differentiation in bovine antral follicles. Biol. Reprod. 39, 573-580.

Tavakkol, A., Simmen, F.A. \& Simmen, R.C. (1988) Porcine IGF-I: cDNA cloning and uterine expression of mRNA encoding evolutionarily conserved IGF-I peptides. Molec. Endocr. 2, 674-681.

van Neste, L., Husman, B., Möller, C., Andersson, G. \& Norstedt, G. (1988) Cellular distribution of somatogenic receptors and insulin-like growth factor-I mRNA in the rat liver. $J$. Endocr. 119, 69-74.

Received 26 January 1990 